\title{
Performance and Evaluation of Various Radiation Based Models for Semi-arid Region
}

\author{
Yadvendra Pal Singh*, H.K. Mittal, Vinay Kumar Gautam and Jalgaonkar Bhagyashri
}

Departmant of Soil \&Water Engineering, Maharana Pratap University of Agriculture and Technology, Udaipur, India

*Corresponding author

\begin{tabular}{|l|}
\hline Ke y w o r d s \\
Radiation models, \\
Solar radiation
\end{tabular}

This study aimed to Performance of seven radiation models. The objective was to determine the most accurate model for estimating solar radiation. Performance and Evaluation of all the models on the same basis is prerequisite for selecting an alternative approach in accordance with available data such as air temperature (Tmax, Tmin, Tmean), actual sunshine hours (n), Relative Humidity (Rhmax, Rhmin \& RHmean) and potential sunshine hours $(\mathrm{N})$. Therefore, recommended Angstrom-Prescott (A-P) model locally calibrated A-P model, Dogniaux-Lemoine (D-L) model, Glower-Meculloch model, Hargreaves-Samani model (1985), Chen et al. (2004), Ertekin and Yaldiz (1999) and Almorox - Hontoria (2004) radiation based model were used to estimate monthly solar radiation (Rs) at Udaipur(Rajasthan), India. Further, the performance of all these methods were evaluated by regression and error analysis between standard Rs derived using FAO recommended Angstrom-Prescott (A-P) model and Rs values estimated using all the six models, on monthly basis. On monthly basis, Glower-Meculloch model performed best with highest coefficient of determination (1.00) and lowest Root mean square error (0.9089) $\mathrm{MJ} \mathrm{m}^{-2}$ day $^{-1}$. Based on overall results it was concluded that the radiation based model provides average monthly accurate estimate of solar radiation compared to other models.

\section{Introduction}

Almost all of the energy that drives the various systems (climate systems, ecosystems, hydrologic systems, etc.) found on the Earth originates from the sun. Solar energy is created at the core of the sun when hydrogen atoms are fused into helium by nuclear fusion. The core occupies an area from the sun's centre to about a quarter of the star's radius. At the core, gravity pulls all of the mass of the sun inward and creates intense pressure. This pressure is high enough to force the fusion of atomic masses. For each second of the solar nuclear fusion process, 700 million tons of hydrogen is converted into the heavier atom helium. Since its formation 4.5 billion years ago, the sun has used up about half of the hydrogen found in its core. The solar nuclear process also creates immense heat that causes atoms to discharge photons. Temperatures at the core are about 15 million degrees Kelvin (27 million degrees F). Each photon that is created travels about 
one micrometer before being absorbed by an adjacent gas molecule. This absorption then causes the heating of the neigh boring atom and it re-emits another photon that again travels a short distance before being absorbed by another atom. This process then repeats itself many times over before the photon can finally be emitted to outer space at the sun's surface. The last $20 \%$ of the journey to the surface the energy is transported more by convection than by radiation. It takes a photon approximately 100,000 years or about 1025 absorptions and re-emissions to make the journey from the core to the sun's surface. The trip from the sun's surface to the Earth takes about 8 minutes.

The irradiative surface of the sun, or photosphere, has an average temperature of about 5,800 Kelvin. Most of the electromagnetic emitted from the sun's surface lies in the visible band cantered at 500 $\mathrm{nm}$ (1 $\mathrm{nm}=10-9$ meters $)$, although the sun also emits significant energy in the ultraviolet and infrared bands, and small amounts of energy in the radio, microwave, X-ray and gamma ray bands. The total quantity of energy emitted from the sun's surface is approximately $63,000,000$ Watts per square meter $(\mathrm{W} / \mathrm{m} 2$ or $\mathrm{Wm}-2)$. The energy emitted by the sun passes through space until it is intercepted by planets, other celestial objects, or interstellar gas and dust. The intensity of solar radiation striking these objects is determined by a physical law known as the Inverse Square Law. This law merely states that the intensity of the radiation emitted from the sun varies with the squared distance from the source. As a result of this law, if the intensity of radiation at a given distance is one unit, at twice the distance the intensity will become only one-quarter. At three times the distance, the intensity will become only one- ninth of its original intensity at a distance of one unit, and so on.

\section{Solar radiation}

Solar radiation is radiant energy emitted by the sun, particularly electromagnetic energy. About half of the radiation is in the visible short-wave part of the electromagnetic spectrum. The other half is mostly in the nearinfrared part, with some in the ultraviolet part of the spectrum. The amount of energy radiated by the sun and the average Earth-sun distance of 149.5 million kilometres, the amount of radiation intercepted by the outer limits of the atmosphere can be calculated to be around $1,367 \mathrm{~W} / \mathrm{m} 2$. Only about $40 \%$ of the solar energy intercepted at the top of Earth's atmosphere passes through to the surface. The atmosphere reflects and scatters some of the received visible radiation. Gamma rays, X-rays, and ultraviolet radiation less than 200 nanometres in wavelength are selectively absorbed in the atmosphere by oxygen and nitrogen and turned into heat energy. Most of the solar ultraviolet radiation with a range of wavelengths from 200 to 300 $\mathrm{nm}$ is absorbed by the concentration of ozone (O3) gas found in the stratosphere. Infrared solar radiation with wavelengths greater than $700 \mathrm{~nm}$ is partially absorbed by carbon dioxide, ozone, and water present in the atmosphere in liquid and vapour forms. Roughly $30 \%$ of the sun's visible radiation (wavelengths from $400 \mathrm{~nm}$ to $700 \mathrm{~nm}$ ) is reflected back to space by the atmosphere or the Earth's surface. The reflectivity of the Earth or and body is referred to as its albedo, defined as the ratio of light reflected to the light received from a source, expressed as a number between zero (total absorption) and one (total reflectance).

Knowledge of the local global solar radiation is required by most models that simulate crop growth, and is also essential for many applications, including evapotranspiration estimates, architectural design, and solar energy systems. Design of a solar energy 
conversion system requires precise knowledge regarding the availability of global solar radiation at the location of interest. Since the global solar radiation reaching the earth's surface depends upon the local meteorological conditions, a study of solar radiation under local climatic conditions is Essential. Solar irradiance can be estimated using empirical models (Almorox, 2011).

Therefore, various methods have been explored by many researchers to estimate, with reasonable accuracy, the solar radiation from other available meteorological data. Parameters used as inputs in the relationships include astronomical factors (solar constant, world-sun distance, solar declination and hour angle); geographical factors (latitude, longitude and altitude); geometrical factors (surface azimuth, surface tilt angle, solar altitude, solar azimuth); physical factors (albedo, scattering of air molecules, water vapour content, scattering of dust and other atmospheric constituents); and meteorological factors (atmospheric pressure, cloudiness, temperature, sunshine duration, air temperature, soil temperature, relative humidity, evaporation, precipitation, number of rainy days, total perceptible water, etc).

Total daily solar radiation is considered as the most important parameter in the performance prediction of renewable energy systems, particularly in sizing photovoltaic (PV) power systems, agriculture and building design applications (Sabziparvar and Shetaee, 2007).

Solar radiation arriving on earth is the most fundamental renewable energy source in nature. a reasonably accurate knowledge of the availability of the solar resource at any place is required by solar engineers, architects, agriculturists, and hydrologists for many applications of solar energy such as solar furnaces, concentrating collectors, and interior illumination of buildings. In spite of the importance of solar radiation measurements, this information is not readily available due to cost, maintenance, and calibration requirements of the measuring equipment (Bakirci, 2009).

A good knowledge of solar radiation is essential for many applications, including agricultural, ecological, hydrological and soil-vegetation-atmosphere transfer models (Liu et al., 2009). Despite its significance, accurate long-term records of solar radiation are not widely available due to the cost of measuring equipment and its difficult maintenance and calibration (Hunt et al., 1998).

Solar energy is the most abundant renewable and sustainable energy source on earth. Due to the nature of solar energy which is inexhaustible and ubiquitous, it can be utilized extensively as an appropriate option to supply the worldwide energy demand and diminish the existing environmental problems such as climate change. Thus, the growth of solar energy technology industry has been significant recently (Gani et al., 2015).

\section{Objectives}

Keeping in view the relevance of precise calculation of solar radiation (Rs) values for monthly average, present study was taken up with following major objectives:

1) To determine monthly average solar radiation: and

2) To compare Rs values obtained from different model with standard model.

\section{Materials and Methods}

This chapter encompasses description of study area, collection and analysis of metrological data and comparison of solar radiation by using six different models with Angstrom-Prescott (A-P) method. 


\section{General description of the study area}

The study was conducted at Maharana Pratap University of Agriculture and Technology, Udaipur $\left(24^{\circ} \mathrm{N}\right.$ latitude, $73^{\circ} \mathrm{E}$ longitude, and $582.17 \mathrm{~m}$ above m.s.1.) in Rajasthan state of India which lies in south slope of the Aravalli Range in Rajasthan. The area has a Sami-arid sub tropical climate with three distinct seasons namely, summer (March- June), monsoon (July- October) and winter season (November- February).

\section{Data collection and analysis of metrological data}

The study was undertaken to estimated solar radiation by using six different models and Angstrom-Prescott (A-P) method. The metrological data on daily basis for the period of seven year (1983-1989), consisting of air temperature (maximum and minimum); relative humidity (maximum and minimum); wind speed; duration of actual sunshine hours, were collected from meteorological observatory situated in the premises of Crop Research Centre of the Maharana Pratap University of Agriculture and Technology, Udaipur.

\section{Estimation of solar radiation}

\section{Angstrom-Prescott (A-P) model}

The A-P model was first proposed by Angstrom in 1924 and further modified by Prescott in 1940. The A-P formula was developed based on the linear relationship between monthly mean daily Rs and sunshine hours as follows:

$$
R_{s}=\left[0.25+0.50\left(\frac{n}{N}\right)\right] R_{a}
$$

Where, Rs is solar radiation $\left(\mathrm{MJ} \mathrm{m} \mathrm{m}^{-2}\right.$ day $\left.^{-1}\right)$, $\mathrm{Ra}$ is extraterrestrial solar radiation $\left(\mathrm{MJ} \mathrm{m}^{-2}\right.$ day $^{-1}$ ), $\mathrm{n}$ is actual sunshine hours (ha), and $\mathrm{N}$ is potential sunshine hours (hs), and a (0.25) and $b \quad(0.50)$ are the empirical A-P coefficients.

\section{Glower-McCulloch model}

Glower and McCulloch (1958) presented the model below to predict global $\mathrm{RS}$ which is valid for $\phi<60 \mathrm{o}$ :

$R_{s}=\left[0.29 \cos \Phi+0.52\left(\frac{n}{N}\right)\right] R_{a}$

Where, Rs is solar radiation $\left(\mathrm{MJ} \mathrm{m} \mathrm{m}^{-2} \mathrm{day}^{-1}\right)$, $\mathrm{Ra}$ is extraterrestrial solar radiation $\left(\mathrm{MJ} \mathrm{m}^{-2}\right.$ day $^{-1}$ ), $\mathrm{n}$ is actual sunshine hours (ha), and $\mathrm{N}$ is potential sunshine hours (hs).

\section{Dogniaux-Lemoine model}

Dogniaux and Lemoine (1983) suggested the following equation, which takes in to account the effect of latitude of the site $(\Phi)$ as an additional input

$R_{a}=\left\{0.37022+\left[0.00506\left(\frac{n}{N}\right)-0.00313\right] \phi+0.32029\left(\frac{n}{N}\right)\right) R_{a} \ldots$

Where, Rs is solar radiation $\left(\mathrm{MJ} \mathrm{m}{ }^{-2}\right.$ day $\left.^{-1}\right)$, $\mathrm{Ra}$ is extraterrestrial solar radiation $\left(\mathrm{MJ} \mathrm{m}^{-2}\right.$ day $^{-1}$ ), $\mathrm{n}$ is actual sunshine hours (ha), and $\mathrm{N}$ is potential sunshine hours (hs).

\section{Hargreaves-Samani model}

According to Hargreaves and Samani (1985), the difference between the maximum and minimum temperature is related to the degree of cloud cover in a given location. Clear-sky conditions result in high temperatures during the day (Tmax) because the atmosphere is transparent to the incoming $\mathrm{RS}$ and in low temperatures during the night (Tmin) because less outgoing long wave radiation is absorbed by the atmosphere. On the other hand, in overcast conditions, Tmax is relatively smaller because a significant part of the 
incoming RS never reaches the earth's surface and is absorbed and reflected by the clouds. Similarly, Tmin will be relatively higher as the cloud cover acts as a blanket and decreases the outgoing longwave radiation. Therefore, the differences between the maximum and minimum temperature (TmaxTmin) can be used as an indicator of the fraction of extraterrestrial radiation that reaches the earth's surface (Hargreaves and Samani 1985). The Hargreaves-Samani formula for estimating RS (MJm-2 day-1) is as follows:

$$
R_{s}=K_{r s} \sqrt{\left(T_{\max }-T_{\min }\right)} R_{a}
$$

where $\mathrm{Ra}$ is the extraterrestrial radiation (MJm-2 day-1), Tmax is the maximum air temperature $\left({ }^{\circ} \mathrm{C}\right)$, Tmin is the minimum air temperature $\left({ }^{\circ} \mathrm{C}\right)$ and $R S K$ is an adjustment factor which was initially set to 0.17 for arid and semi-arid regions.

Hargreaves (1994) later recommended values of 0.16 and 0.19 for inland and coastal regions, respectively. Daily $\mathrm{Ra}$ is given by the following equation (Allen et al., 1998):

Chen et al., (2004) proposed the following model:

$R_{a \alpha}=\left[0.28 \ln \left(T_{\max }-T_{\min }\right)-0.15\right] R_{\alpha}$

where $\mathrm{Ra}$ is the extraterrestrial radiation $\left(\mathrm{MJm}^{-2}\right.$ day $\left.^{-1}\right)$, Tmax is the maximum air temperature $\left({ }^{\circ} \mathrm{C}\right)$, Tmin is the minimum air temperature $\left({ }^{\circ} \mathrm{C}\right)$

\section{Ertekin and Yaldiz}

Ertekin and Yaldiz (1999) reported that RS can be calculated by the following Equation

$R_{s}=-4.46+0.477 R_{a}+0.226 \mathrm{~T}$

where $\mathrm{Ra}$ is the extraterrestrial radiation (MJm-2 day-1), Tmean is the mean air temperature $\left({ }^{\circ} \mathrm{C}\right)$.

\section{Almorox-Hontoria model}

Almorox and Hontoria (2004) have suggested an exponential type model as:

$R_{s}=\left[-0.071+0.3096 \exp \left(\frac{n}{N}\right)\right] R_{a}$

Where, Rs is solar radiation $\left(\mathrm{MJ} \mathrm{m}{ }^{-2}\right.$ day $^{-1}$ ), $\mathrm{Ra}$ is extraterrestrial solar radiation $\left(\mathrm{MJ} \mathrm{m}^{-2}\right.$ day $^{-1}$ ), $\mathrm{n}$ is actual sunshine hours (ha), and $\mathrm{N}$ is potential sunshine hours (hs),

\section{Results and Discussion}

The present study was carried out to determine solar radiation value for metrological observatory of Department of Soil and Water Engineering, College of Technology Agriculture engineering situated in Udaipur district of Rajasthan state by using value of Rs obtained with Angstrom-Prescott (A-P) model and various radiation based model to assess performance of various models for determining the Rs value.

Comparison of Rs value determined by various model with Angstrom-Prescott (A$P$ ) method model on average monthly basis

The data related to comparison between Observed values and Estimated values Monthly average daily solar radiation $\left(\mathrm{MJm}^{-2}\right.$ day $^{-1}$ ) for six Models are presented in Table 1.

Daily solar radiation by various equations was estimated and compared with observed radiation at the weather station. Figure 1 showed that the values of solar radiation for Dogniaux-Lemonine model were overestimated from Angstrom-Prescott (A-P) model for June, July and August by 1.39, 9.16 and $14.61 \%$ respectively and underestimated for remaining months. The values of solar 
radiation for Almonrox-Hontria (2004) model were underestimated from Angstrom-Prescott (A-P) model in all months. the GlowerMeculloch model were overestimated from Angstrom-Prescott (A-P) model for all 12 months by 4.61, 4.61, 4.66, 4.66, 4.67, 4.76, $4.92,5.04,4.72,4.62$ and $4.60 \%$ respectively. For Ertekin-Xaldiz (1999) model were overestimated with observed model in two month (July and August) by 10.92 and 25.32 and underestimated for remaining months. the value of solar radiation for Hargreaves-
Samani model were overestimated with observed model in the six months (January, February, March, October, November and December) by $9.00,4.01,6.63,7.34,11.53$ and $15.16 \%$ respectively and underestimated in all months. the Chen et al., (2004) model were overestimated from Angstrom-Prescott (A-P) model for January, February, march, October, November and December by $5.71 \%$, $1 \%, 3.76 \%, 4 \%, 7.31 \%$, and $11.19 \%$ respectively and underestimated for remaining months.

Table.1 The comparison between observed values and estimated values monthly average daily solar radiation $\left(\mathrm{MJm}^{-2} \mathrm{day}^{-1}\right)$ for six Models

\begin{tabular}{|c|c|c|c|c|c|c|c|c|c|c|c|c|}
\hline \multirow[t]{2}{*}{ MODEL } & \multicolumn{12}{|c|}{ MONTHS } \\
\hline & Jan & Feb & March & April & May & June & July & Aug & Sept & Oct & Nov & Dec \\
\hline Observes & 15.5072 & 19.1096 & 21.3236 & 24.4313 & 25.6978 & 23.0783 & 18.6527 & 15.4949 & 19.3408 & 18.5381 & 16.0132 & 14.1019 \\
\hline $\begin{array}{l}\text { Dogniaux- } \\
\text { Lemonine }\end{array}$ & 14.6085 & 17.9606 & 20.5257 & 23.5508 & 24.9440 & 23.4000 & 20.3627 & 17.7590 & 19.2264 & 17.4847 & 14.9593 & 13.3479 \\
\hline $\begin{array}{l}\text { Almonrox- } \\
\text { Hontria }\end{array}$ & 13.0213 & 16.0814 & 17.4843 & 20.0004 & 20.9046 & 18.4614 & 14.8128 & 12.4836 & 15.5367 & 15.5520 & 13.5707 & 11.8003 \\
\hline $\begin{array}{l}\text { Glower- } \\
\text { Meculloch }\end{array}$ & 16.2233 & 19.9913 & 22.3175 & 25.5707 & 26.8999 & 24.1786 & 19.5722 & 16.2763 & 20.2550 & 19.3947 & 16.7502 & 14.7618 \\
\hline $\begin{array}{l}\text { Ertekin- } \\
\text { Xaldiz }\end{array}$ & 10.7612 & 13.5958 & 17.0328 & 20.1747 & 21.9487 & 21.7169 & 20.7004 & 19.4176 & 17.6685 & 14.4949 & 11.6891 & 10.0041 \\
\hline $\begin{array}{l}\text { Hargreaves- } \\
\text { Samani }\end{array}$ & 16.9043 & 19.8761 & 22.7379 & 24.3345 & 23.5234 & 20.1447 & 16.0104 & 14.9601 & 18.0892 & 19.9164 & 17.8601 & 16.2406 \\
\hline Chen & 16.3936 & 19.3020 & 22.1269 & 23.7686 & 23.1301 & 19.5687 & 14.5271 & 13.4661 & 17.6542 & 19.2811 & 17.1845 & 15.6805 \\
\hline
\end{tabular}

Table.2 Statistical comparison between observed $\mathrm{R}_{\mathrm{s}}$ values and those estimated by the six models

\begin{tabular}{|l|c|l|}
\hline Models & $\mathbf{R}^{\mathbf{2}}$ & $\begin{array}{l}\text { RMSE }\left(\mathbf{M J m}^{-2}\right. \\
\text { day }^{-1} \text { ) }\end{array}$ \\
\hline $\begin{array}{l}\text { Glower- } \\
\text { Meculloch }\end{array}$ & 1.000 & 0.9089 \\
\hline $\begin{array}{l}\text { Almorox- } \\
\text { Hontria }\end{array}$ & 0.989 & 3.4656 \\
\hline Dogniaux & 0.908 & 0.9799 \\
\hline H-G & 0.763 & 1.5473 \\
\hline Chen & 0.726 & 1.6624 \\
\hline Ertekin-Xaldiz & 0.561 & 3.6663 \\
\hline
\end{tabular}


Fig.1 Comparison between the Observed and estimated values by various models of solar radiation

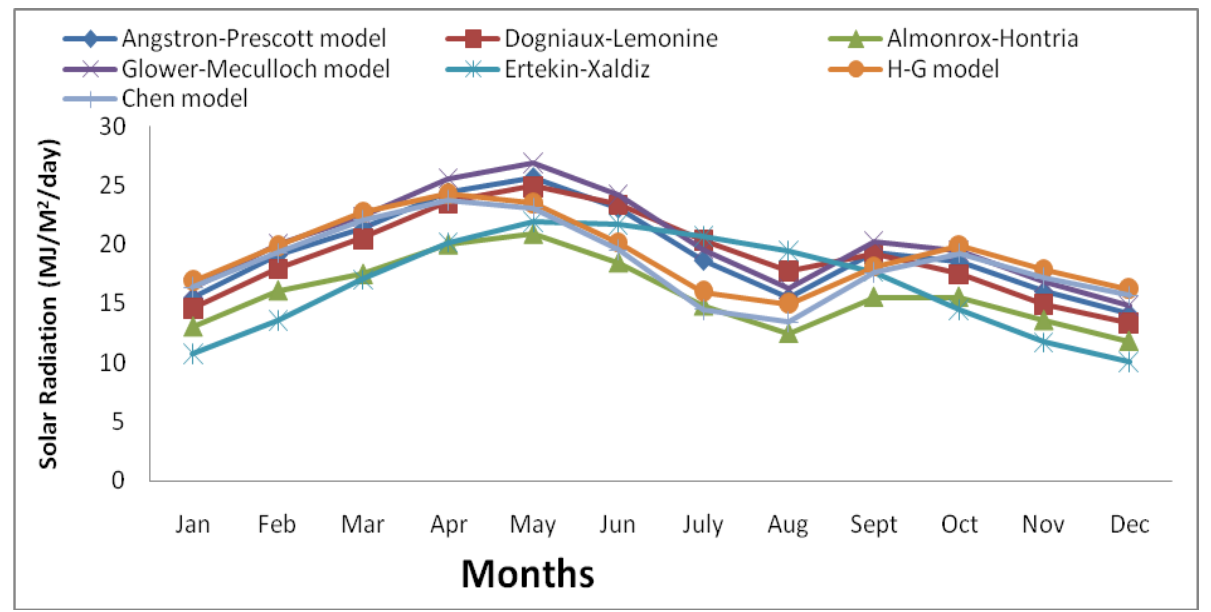

Fig.2 Estimated radiation from Dogniaux-Lemonine model against measured radiation

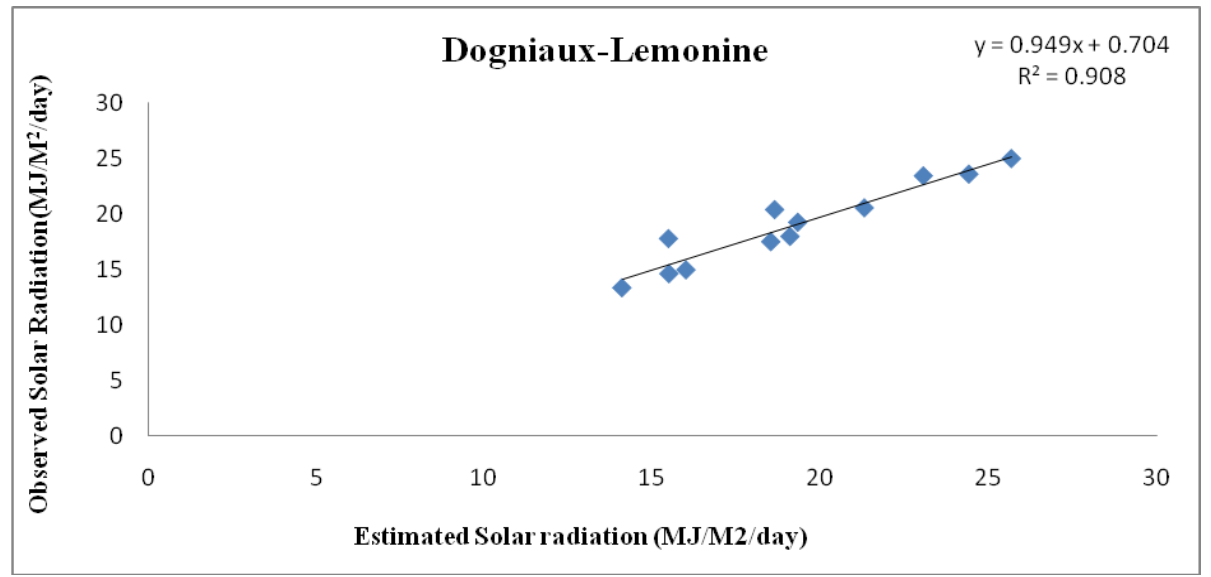

Fig.3 Estimated radiation from Almonrox-Hontria model against measured radiation

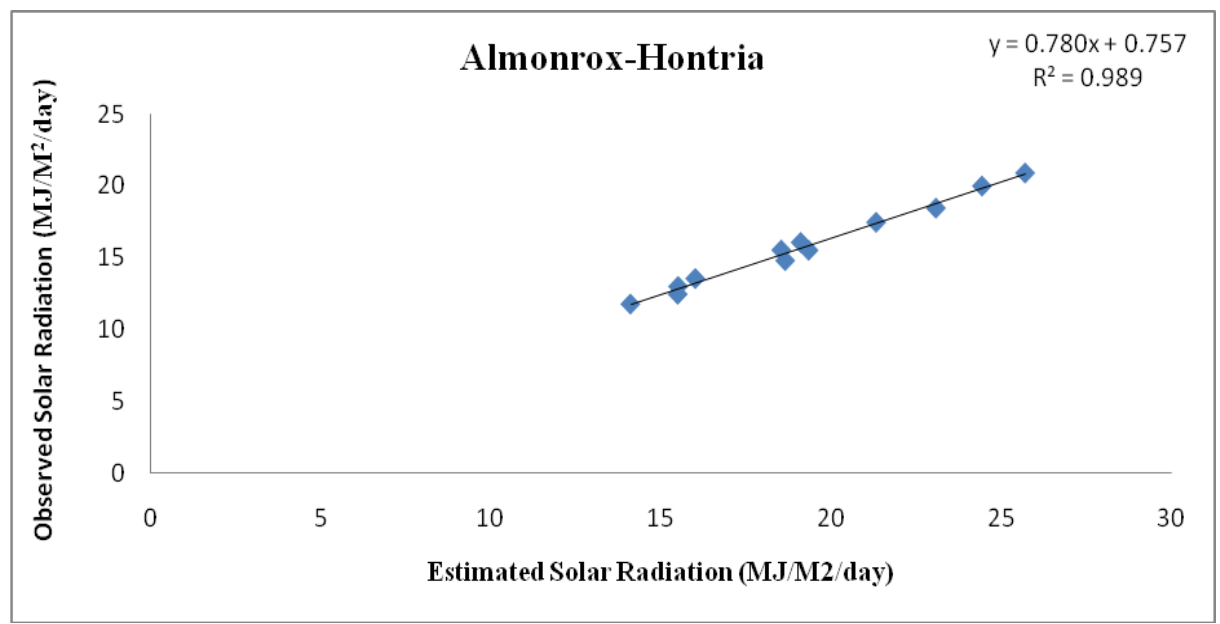


Fig.4 Estimated radiation from Glower-Meculloch model against measured radiation

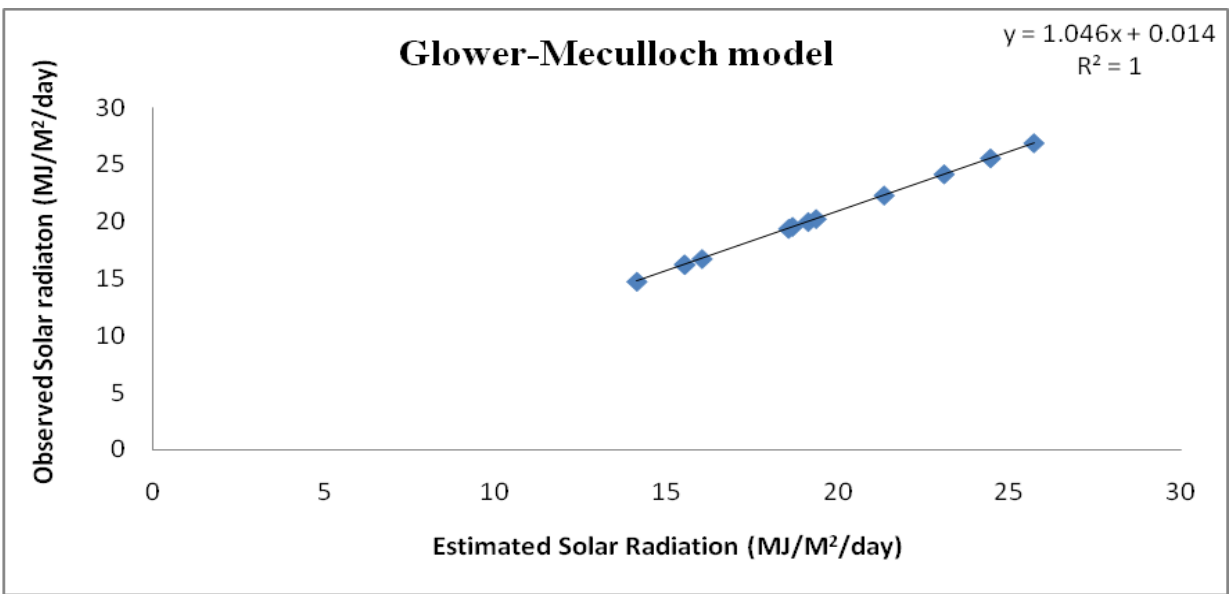

Fig.5 Estimated radiation from Ertekin- Xaldiz model against measured radiation

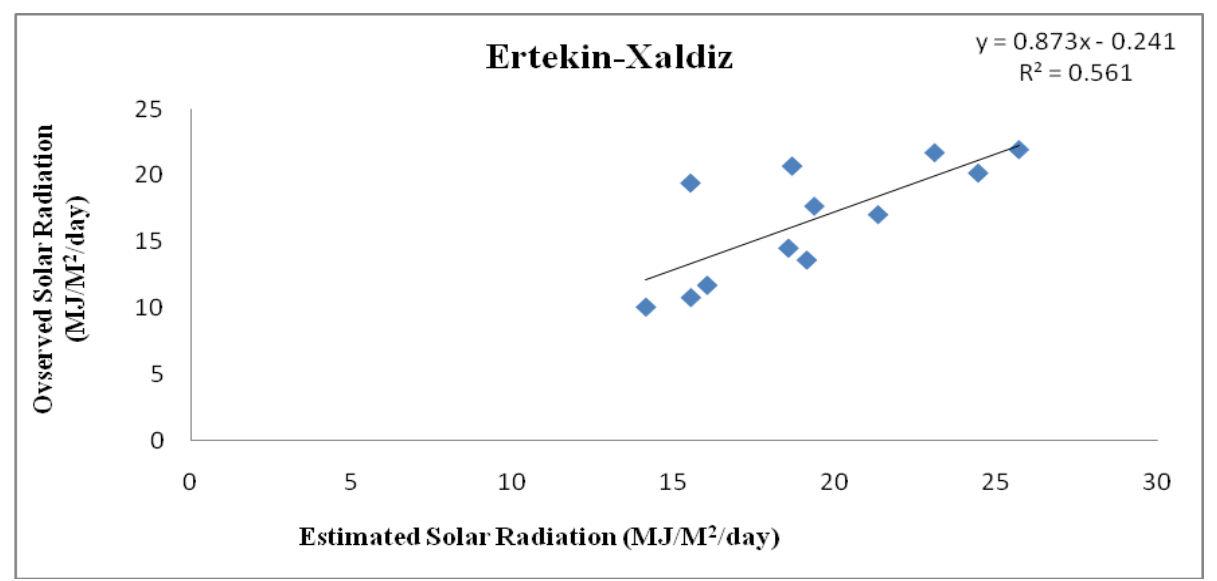

Fig.6 Estimated radiation from Chen model against measured radiation

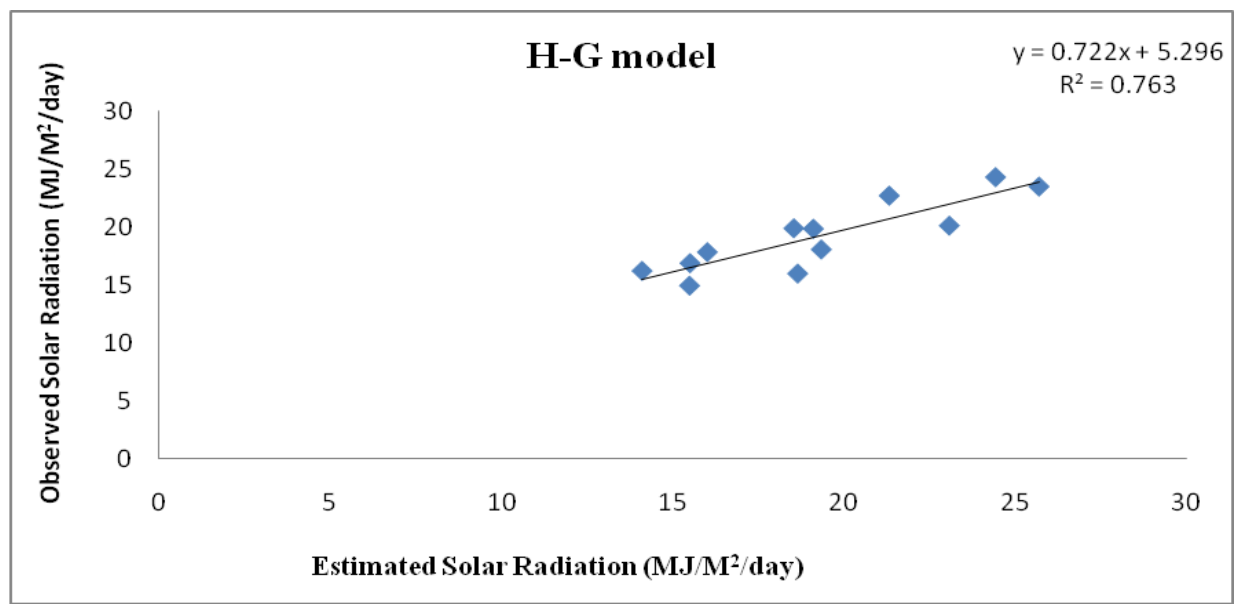


Fig.7 Estimated radiation from Chen et al., (2013) model against measured radiation

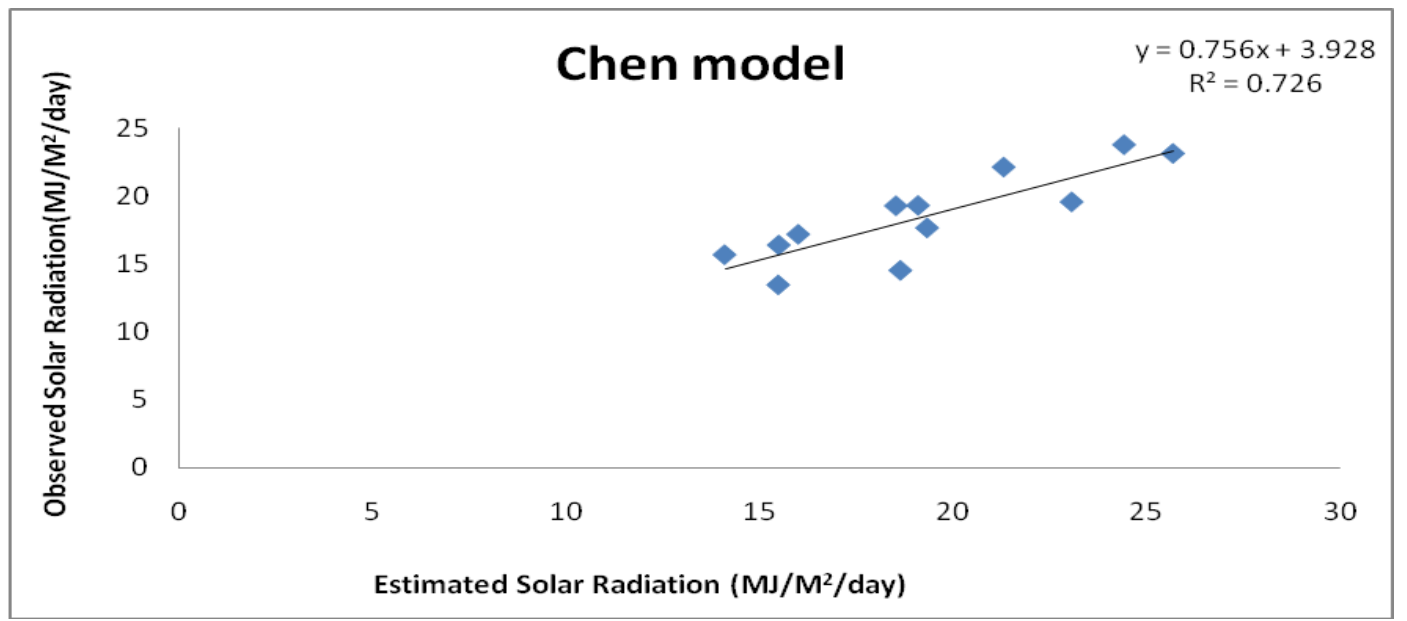

\section{Statistics comparison}

The statistical analyses for various radiation models are presented Table 2. A linear regression between the Rs values estimated by six models and the values observed in weather station is presented for AngstromPrescott (A-P) model. In each section of figure 2 to 6 , the equation of regression line and coefficient of determination $\left(\mathrm{R}^{2}\right)$ are represented. Characteristics of regression line and the amounts of statistical indices resulting from comparison are represented also in Table 2. Table 2 showed that the values of coefficient of determination and root mean square error for various model.

The highest $\mathrm{R}^{2}$ values were found for GlowerMeculloch model with a value of 1 and lowest for Ertekin - Yaldiz (1999) model with a value of 0.561 . Similarly the highest RMSE value was found for Almonrox-Hontria (2004) model with a value of 3.4656 and lowest for Glower-Meculloch model with a value of 0.9089 (Fig. 7).

The result revealed that Glower-Meculloch model was more accurate method for calculating solar radiation.
Summary and conclusion are as follows

The main objective of this study was to determine value of solar radiation by various models as suggested by Hargreaves-Samani, Glower-Meculloch, Chen et al., (2004), Ertekin and Yaldiz (1999), Almorox and Hontoria (2004), and Dogniaux-Lemonine in comparison to that observed by AngstromPrescott (A-P) model on the basis of long term daily meteorological dataset of 7 year (1983-1989) recorded at udaipur $\left(24^{\circ} 35^{\prime} \mathrm{N}\right.$ latitude, $73^{\circ} 42^{\prime} \mathrm{E}$ longitude, and $582.17 \mathrm{~m}$ above m.s.l.) in Rajasthan state of india. The other objective in this study includes, compareson analysis of monthly average of Rs values calculated by A-P model and various models.

The study was carried out at the Maharana Pratap University of Agriculture and Technology, Udaipur (Raj.) situated in southern region of Rajasthan region having a semi-arid sub tropical climate.

On monthly basis, average value of Rs determined by various model analysis varied from 26.8998 to 10.0409 with maximum value for the month of may and minimum for the month of December. 
The good correlation was observed between Rs estimated by models proposed by GlowerMeculloch and Almorox-Hontoria (2004) Model.

The Glower-Meculloch model was more accurate method for calculating solar radiation compared to other various radiation based models.

\section{References}

Ahmed, F., Aqil, Burney. S. M. and Husain, S. A., 1991. Monthly average daily global beam and diffuse solar radiation and its correlation with hours of bright sunshine for Karachi, Pakistan. Renewable Energy., 1(1): 115- 118.

Aksoy, B. U., Rusen, S. E. and Akinoglu, B. G., 2011. A simple correlation to estimate global solar irradiation on a horizontal surface using METEOSAT satellite images Turkish. J. Eng. Env. Sci., 35: $125-137$.

Álvarez, J., Mitasova, H. and Allen, H. Lee., 2011. Estimating monthly solar radiation in south- central chile. Chilean Journal of Agricultural Research. 71(4).

Almorox, J., 2009. Estimating global solar radiation from common meteorological data in Aranjuez. Spain. Turk. J. Phys., 35: $53-64$.

Aladenola, O.O., and Madramootoo, C. A., 2014. Evaluation of solar radiation estimation methods for reference Badescu, V and Dumitrescu, A., 2015. Simple solar radiation modelling for different cloud types and climatology. Throe. Appl. Climatol., 124: 141-160. evapotranspiration estimation in Canada. Theory Apply Climatol., 118: 377-385.

Benghanem, M., and Mellit., 2013. A simplified calibrated model for estimating daily global solar radiation in Madinah, Saudi Arabia. Theor. Appl. Climatol., 115: 197-205

Bakirci, Kadir., 2009. Correlations for estimation of daily global solar radiation with hours of bright sunshine in Turkey. Energy., 34: 485-501.

Bannani, F. K, S. T. and A, Ben-Khalifa. A., 2006. Estimation of monthly average solar radiation in Libya. Theor. Apply Climatol., 83: 211-215.

Chen, J., Long. and Li, Guo-Sheng., 2013. Evaluation of support vector machine for estimation of solar radiation from measured meteorological variables. Theor. Appl. Climatol., 115: 67-638.

Gadiwala, S. M., Usman, A., Akhtar, M. and Jamil, K., 2.013. Empirical models for the estimation of global solar radiation with sunshine hours on horizontal surface in various cities of pakistan., 18(9).

Gana, N.N., and Akpootu, D. O., 2013. Angstrom type empirical correlation for estimating global solar radiation in north-eastern Nigeria.

Lke, C. U., 2013. Climatological Effects of total solar radiation in awake, Nigeria. IOSR Journal of Applied Physics., 5(2): 51-54.

Irmak, S., Irmak, A., Allen, R. G. and Jones, J.W., 2003. Solar and net radiationbased equations to estimate reference evapotranspiration in humid climates. Journal of Irrigation and Drainage Engineering., (97): 0733- 9437.

I U. A. and U, U. J., 2011. Performance assessment of Hargreaves model in estimating solar radiation in Abuja using minimum climatological data. International Journal of the Physical Sciences., 31(6): 7285 - 7290.

Jacobs, J. M., Anderson, M. C., Friess, L. C. and Diak,G. R., 2004. Solar radiation, long wave radiation and emergent wetland evapotranspiration estimates from satellite data in Florida, USA. Hydrological Sciences- JournaldesSciences Hydrologiques., 49(3).

Li, H., Cao, F., Bu, X. And Zhao, 1., 2014. 
Models for calculating daily global solar radiation from air temperature in humid regions a case study. DOI 10.1002/ep.12018.

Lyra, G.B., Zanetti, S. S. and Santos, A. R., 2015. Estimation of monthly global solar irradiation using the hargreavessamani model and an artificial neural network for the state of Alagoas in north eastern Brazil. 10.1007/s00704-0151541-8.

Mubiru, J., B, E., D, U. and F, Senyonga. T., 2007. Assessing the performance of global solar radiation empirical formulations in Kampala, Uganda. Theor. Appl. Climatol., 87: 179-184.

Muzathik, A. M., Ibrahim, M. Z., Samo, K. B. and Wan, N. W. B., 2011 Estimation of global solar irradiation on horizontal and inclined surfaces based on the horizontal measurements. Energy., 36: 812-818.

Myers, D. R., 2003. Solar Radiation modelling and measurements for renewable energy applications. Data and Model Quality., CP-560-33620.

Mubiru, J., Karume, K., Majaliwa, M., Banda, E. J. K. B. and Otiti, T., 2007. Interpolating methods for solar radiation in Uganda. Theor. Appl. Climatol., 88: 259-263.

Mghouchi, Y. El., Bouardi, A. El., Choulli, Z. and Ajzoul, T., 2014. New model to estimate and evaluate the solar radiation. International Journal of Sustainable Built Environment., (3): 225-234

Moradi, I., Mueller, R. and Perez, R., 2014. Retrieving daily global solar radiation from routine climate variables. Theor. Appl. Climatol., 116: 661-669.

Muzathik, M. A., Nik, W. M. B. W., Samo, K. B. and Ibrahim, M. Z., 2010. Reference solar radiation year and some climatology aspects of east coast of west malaysia. American J. of Engineering and Applied Sciences., 3(2): 293-299.

Namrata, K., Sharma, S. P. and Saksena, S. B.
L., 2013. Comparison of different models for estimation of global solar radiation in Jharkhand (India) Region. Smart Grid and Renewable Energy., 4: 348-352.

Olmo, F. J., Vida, J., Morons, F., Tovar, J. and Alados- Arboledas, L., 2001. Performance reduction of solar irradiance parametric models due to limitations in required aerosol data: case of the CPCR2 model. Theor. Appl. Climatol., 69: 253-263.

Ouali, K., and Alkama, R. 2014. A new Model of global solar radiation based on meteorological data in Bejaia City (Algeria). Energy Procedia., 50: 670 676.

Okonkwo, N, G. and Sc, M., 2014. Estimating global solar radiation from temperature date in minna location. European Scientific Journal., 10(15): 1857 - 7881.

Rivington, M., Bellocchi, G., Matthews, K. B. and Buchan, K., 2005. Evaluation of three model estimations of solar radiation at 24 UK stations. Agricultural and Forest Meteorology., 132: 228-243.

Riza, D., F. A., Gilani, S. I. H., and Aris, M.S., 2011. Hourly solar radiation estimation using ambient temperature and relative humidity data. International Journal of Environmental Science and Development., 3(2).

Sabziparvar, Ali. A. and Farahani, M. M., 2009. An improved estimation of daily clear- sky biologically EER from broadband global solar radiation. Int. J. Biometeorol., 53: 239-245.

Sabziparvar, Ali. A., Sabziparvar., Mousavi, R., Marofi, S., Heidari, M., and Ebrahimi Pak, N. A. 2014. Calibration of angström-prescott solar radiation model for more accurate estimation of reference evapotranspiration in the absence of observed solar radiation (AEMS)., 6-7.

Sarkar, N.I., 2016. Estimation of solar 
radiation from cloud covers data of Bangladesh. Renewable., 3: 11.

Samani, Z., 2000. Estimating solar radiation and evapotranspiration using minimum climatological data. Journal of Irrigation and Drainage Engineering., 126 (4): 0733-9437.

Shamim, M., Bray, M., Remesan, R. and Han, D., 2015. A hybrid modelling approach for assessing solar radiation. Theor .Appl. Climatol., 122: 403-420.

Toğrul, I.T., 2009. Estimation of solar radiation from angstroms coefficients by using geographical and meteorological data in bishkek, Kyrgyzstan. Is bilimi ve Teknigi Dergisi., 29(2): 99-108.

Tabari, H., T, P. H., Willems, P. And Martinez, C., 2014. Validation and calibration of solar radiation equations for estimating daily reference evapotranspiration at cool semi-arid and arid locations. Hydrological Sciences Journal., DOI: 10.1080/02626667.2014.947293.

Prem, W.P., and Paz, J. O., 2011. Evaluation of Various Methods for Estimating Global Solar Radiation in the Southeastern United States., DOI: 10.1175/JAMC-D-11- 0141.1.

Xu, C.Y., and Singh, V. P., 2000. Evaluation and generalization of radiation-based methods for calculating evaporation. Hydrol. Process., 14(2): 339-349.

Yakubu, D. and W, M. D., 2012. Relationship between the global solar radiation and the sunshine duration in abuja, Nigeria. Turkish Journal of Physics 27(2):161167.

Zhang, Y.L., Qin, B. Q. and Chen, W. M., 2004. Analysis of 40 year records of solar radiation data in Shanghai, Nanjing and Hangzhou in Eastern China. Theor. Appl. Climatol., 78: 217-227.

Zamani, M., (2015). Temperature-based estimation of global solar radiation using soft computing methodologies. Theor. Appl. Climatol., doi:10.1007/s00704015-1487-x.

\section{How to cite this article:}

Yadvendra pal Singh, H.K. Mittal, Vinay Kumar Gautam and Jalgaonkar Bhagyashri. 2019. Performance and Evaluation of Various Radiation Based Models for Semi-arid Region. Int.J.Curr.Microbiol.App.Sci. 8(04): 2108-2119. doi: https://doi.org/10.20546/ijcmas.2019.804.248 